\author{
ANNA JANISZEWSKA \\ Uniwersytet Łódzki \\ Wydział Nauk Geograficznych \\ Katedra Studiów Ludnościowych i Badań nad Usługami
}

\title{
OBRAZ STAROŚCI DEMOGRAFICZNEJ W KRAJACH UE A STAN ZDROWIA JEJ MIESZKAŃCÓW
}

\section{THE IMAGE OF DEMOGRAPHIC OLD AGE IN THE COUNTRIES OF EU AND THE HEALTH OF ITS INHABITANTS}

Artykuł wpłynął do redakcji 20.10.2015; po recenzjach zaakceptowany 23.05.2016.

Janiszewska A., 2015, Obraz starości demograficznej $w$ krajach UE a stan zdrowia jej mieszkańców, [w:] Janiszewska A. (red.), Jakość życia ludzi starych - wybrane problemy, ,Space - Society - Economy”, 14, Department of Population and Services Studies, Wydawnictwo Uniwersytetu Łódzkiego, Łódź, s. 25-48.

Dr hab. Anna Janiszewska, Uniwersytet Łódzki, Katedra Studiów Ludnościowych i Badań nad Ustugami, ul. Kopcińskiego 31, 90-142 Łódź;

e-mail: anna.janiszewska@geo.uni.lodz.pl

\section{Zarys treści}

W krajach UE 28 obserwujemy od wielu lat starzenie się ludności. Jest to proces zróżnicowany przestrzennie. Powiększanie się odsetka ludzi starych nie pozostaje bez wpływu na sytuację zdrowotną społeczeństw. Wśród czynników wpływających na jakość życia ludzi starych, ich stan zdrowia jest elementem bardzo istotnym, związanym z potrzebą subiektywnego odczuwania satysfakcji ze swojego pełnego potencjału zdrowotnego i pełnienia aktywnego życia społecznego. Celem opracowania jest zaprezentowanie wybranych aspektów procesu starzenia się ludności krajów unijnych oraz wybranych aspektów zdrowotnej charakterystyki mieszkańców powyżej 65. roku życia w krajach unijnych. 


\section{Słowa kluczowe}

Starzenie się ludności, stan zdrowia ludności, subiektywna ocena stanu zdrowia, kraje UE 28.

\subsection{WPROWADZENIE}

Starzenie się ludności to jeden z najważniejszych procesów demograficznych XXI wieku wywołujący nie tylko skutki demograficzne, ale także mający wymierne konsekwencje społeczne i ekonomiczne. Czynnikami bezpośrednio wpływającymi na starzenie się ludności są przeszłe i bieżące trendy w zakresie rodności, umieralności (zwłaszcza w starszym wieku) oraz migracji (rys. 1). Pierwszy z nich jest związany ze stałym spadkiem poziomu płodności i rodności, co w konsekwencji przyczynia się do zmniejszenia udziału najmłodszej części społeczeństwa (starzenie od „podstawy piramidy wieku”). Społeczeństwa starzeją się także od „wierzchołka piramidy”, w wyniku zmniejszenia śmiertelności w starszych grupach wieku i wydłużanie się trwania życia obu subpopulacji ludzi. Trzecim bezpośrednim czynnikiem warunkującym proces starzenia są ruchy wędrówkowe ludności. Jak wynika z badań, migrują głównie ludzie młodzi i obszary napływowe ulegają procesowi odmładzania populacji, natomiast regiony emigracyjne charakteryzuje znaczne przyspieszenie procesu starzenia się, prowadzące często do ich depopulacji. Zahamowanie fali napływu ludności, związane np. z nasyceniem rynku pracy, może za jakiś czas spowodować wzrost dynamiki starzenia się obszaru napływowego, o nie spotykanej wcześniej skali, gdyż osoby napływowe wejdą w wiek poprodukcyjny. Dodatkowym elementem wpływającym na starzenie się populacji jest zwiększające się natężenie migracji osób w starszym wieku. Obszary napływowe o atrakcyjnych walorach krajobrazowych czy klimatycznych stają się docelowym miejscem ludzi starszych i stąd ich udział w ludności tych obszarów znacząco wzrasta. Literatura dotycząca starzenia się ludności, przyczyn i skutków tego procesu jest bardzo bogata (Okólski 1990, 2005; Długosz 1996; Grundy 1996; Golini 1997; King, Warnes, Williams 1998; Kurek 1998; Kotowska 1999; Szukalski 1998, 2004, 2006; King, Jackson 2000; Dyson 2001; Kinsella, Velkoff 2001; Mirkin, Weiberge 2001; Frąckiewicz 2002; Frątczak 2002; Avramov, Maskova 2003; Eurostat 2004; Reher 2004; Kinsella, Philips 2005; Długosz, Kurek 2006; Kowaleski 2008; Długosz, Kurek, Kwiatek-Sołtys 2011; Nowak-Far 2011; Błędowski 2014; Walker 2014).

Starość i starzenie się to pojęcia, które nie zostały jeszcze jednoznacznie zdefiniowane ani przez nauki społeczne ani biologiczne. Pierwsze z tych pojęć traktowane jest jako zjawisko, faza życiowa, drugie natomiast jest procesem. Starość jako etap, stan w życiu człowieka ma charakter statyczny, natomiast starzenie się, traktowane jako proces rozwojowy, jest zjawiskiem dynamicznym. Starzenie się w ujęciu biologicznym zdefiniować można jako stopniowe zmniejszenie rezerwy 
czynnościowej narządów, które zmniejszają możliwość zachowania równowagi ustrojowej. Jest to proces ciągły i nieodwracalny, przebiegający etapami. Najpierw następuje etap starzenia się społecznego, rozumiany jako faza życia, w której ustaje aktywność zawodowa jednostki i przestaje ona pełnić role zawodowe. Najczęściej wyróżnia się cztery okresy starości: 60-69 lat - wiek początkowej starości; 70-74 lata - wiek przejściowy między początkową starością a wiekiem ograniczonej sprawności fizycznej i umysłowej; 75-84 lata - wiek zaawansowanej starości; 85 lat i więcej - niedołężna starość. Inną klasyfikacją stosowaną do okresu starości jest podział tej fazy życia na dwa podokresy: wczesną starość (określaną także jako wiek podeszły, „młodsi starzy”) obejmującą wiek 60-74 lata oraz późną starość (starość właściwa, ,starsi starzy”), obejmującą wiek 75-89 lat. Wyodrębnia się również kategorię osób długowiecznych w wieku 90 lat i więcej jako kategorię o szczególnych cechach biologicznych i dziedzicznej predyspozycji do długiego życia (Golinowska i in. 1999).

Demografowie proces starzenia się ludności definiują jako wzrost odsetka ludzi powyżej 60. (granica używana na kontynencie europejskim) lub 65. roku życia (propozycje ONZ, akceptowane w USA i Wielkiej Brytanii). Starzenie się ludności jest konsekwencją zmiany reżimu reprodukcji (odtwarzania się) ludności: od reprodukcji rozrzutnej, odznaczającej się wysokim natężeniem urodzeń i zgonów, do reprodukcji oszczędnej z niską rodnością i umieralnością. Powyższe przemiany ujęte są w syntetyczny sposób w koncepcji przejścia demograficznego i towarzyszących temu przejściu dwóch innych, długookresowych zmian — przejściu epidemiologicznemu i przejściu zdrowotnemu (Szukalski 2008).

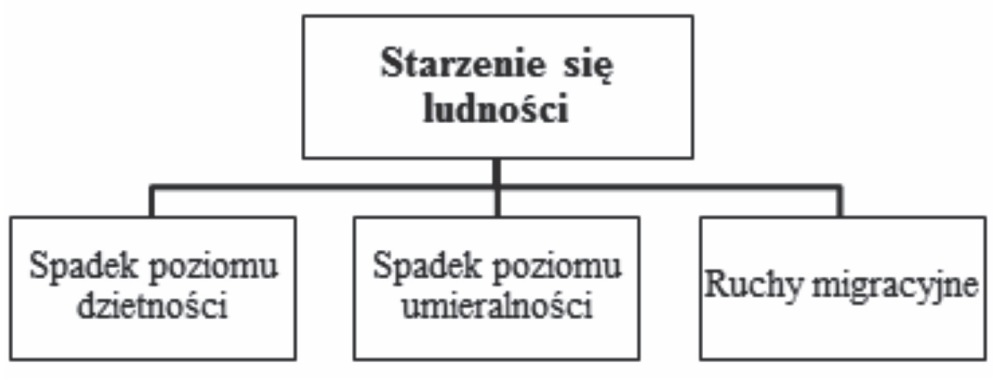

Rys. 1. Czynniki wpływające na starzenie się ludności

Źródło: opracowanie własne

Za podstawowe cechy starości uważa się postępujące ograniczenie samodzielności życiowej, znaczny spadek zdolności adaptacyjnych człowieka w wymiarze biologicznym, psychospołecznym oraz stopniowe nasilenie się zależności od otoczenia. Starość jest okresem, w którym pogorszeniu ulega stan zdrowia jednostki, dlatego też jedną z ról społecznych, jakie pełnią osoby starsze, jest rola 
chorego (Pierzchalska, Klag 2008). Zmiany sytuacji zdrowotnej ludzi starych wpływają w oczywisty sposób na ich jakość życia.

Jeżeli jakość życia rozumiemy jako subiektywne poczucie zaspokojenia potrzeb, to należy stwierdzić, że w przypadku ludzi starych rozpatrując to pojęcie powinno uwzględniać się pewne specyficzne dla tej grupy wiekowej problemy społeczne, które nie dotyczą osób będących na wcześniejszych etapach życia. W analizie jakości życia ludzi starych należy odnieść się do czterech podstawowych kategorii: komunikacji (społecznej), zdrowia, autonomii i korzystania z usług instytucji (Lauder 1998).

Artykuł podejmuje problematykę jakości życia ludzi starych (w wieku 65 lat i więcej) w aspekcie ich stanu zdrowia. Analiza objęła mieszkańców krajów UE 28, ponieważ pod względem zaawansowania procesu starzenia się ludności Europa jest kontynentem o największym jego poziomie. W opracowaniu zaprezentowano wybrane aspekty procesu starzenia się ludności krajów unijnych. Zdrowotną charakterystykę mieszkańców powyżej 65. roku życia w krajach unijnych przedstawiono uwzględniając długość życia, długość życia w zdrowiu, a także subiektywną ocenę stanu ich zdrowia.

\subsection{STARZENIE SIĘ LUDNOŚCI W KRAJACH UE 28}

Miarą obrazującą poziom starzenia się ludności jest udział osób starych (65 lat i więcej) w całej populacji. Odsetek ludzi starych w Unii rośnie, w latach 2004 2014 wzrósł nieco ponad 2\%. Największe przyrosty względne osób 65+ odnotowały w tym okresie Malta (4,9\%), Finlandia (3,8\%), Holandia (3,5\%), Czechy (3,4\%) i Dania (3,3\%). W 2014 roku krajami „najstarszymi demograficznie”, w których więcej niż co piąty mieszkaniec miał 65 lat i więcej były Włochy $(21,4 \%)$, Niemcy $(20,9 \%)$ i Grecja (20,5\%). Najmniejsze udziały osób starych w całej populacji zaobserwowano w Irlandii (12,6\%) i Słowacji (13,5\%) - rys. 2. Według prognozy sporządzonej przez Eurostat udział osób starych w 2050 roku przekroczy 30\% w sześciu krajach unijnych. Będą to Portugalia (34,6\%), Grecja (33,9\%), Hiszpania $(33,4 \%)$, Niemcy $(31,8 \%)$, Słowacja $(31,0 \%)$ i Bułgaria $(30,1 \%)$. W Polsce udział osób $65+$ zbliży się do $30 \%$. Prognozy zakładają, że do grupy państw o zaawansowanym procesie starzenia się ludności (Niemcy, Włochy, Grecja) dołączą nowe kraje, które wcześniej uznawane były, w skali europejskiej, jako społeczeństwa „młodsze” demograficznie (jak np. Słowacja i Polska).

Poziom starzenia demograficznego $\mathrm{w}$ krajach unijnych mierzony indeksem starości demograficznej (ISD) wskazuje na znaczny stopień zaawansowania tego procesu. Wartości ISD, które wyrażają relację pomiędzy ludnością w wieku 65 lat i więcej a ludnością w wieku 0-14 lat już w 2004 roku osiągnęły wartość 100, co oznaczało równowagę liczebną pomiędzy tymi grupami. Od 2005 roku wartości indeksu starości demograficznej dla ludności UE były już większe niż 
100. Prognoza demograficzna zakłada, że w 2050 roku liczba ludzi starych będzie blisko dwukrotnie wyższa niż dzieci i młodzieży (rys. 3). Wśród krajów Unii w 2014 roku tylko w siedmiu z nich liczba dzieci i młodzieży była większa niż liczba ludzi starych, należały do nich: Irlandia, Cypr, Luksemburg, Słowacja, Wielka Brytania, Francja i Polska. W pozostałych krajach ISD osiągnęło wartości od 102 w Holandii do 158 w Niemczech ${ }^{1}$.

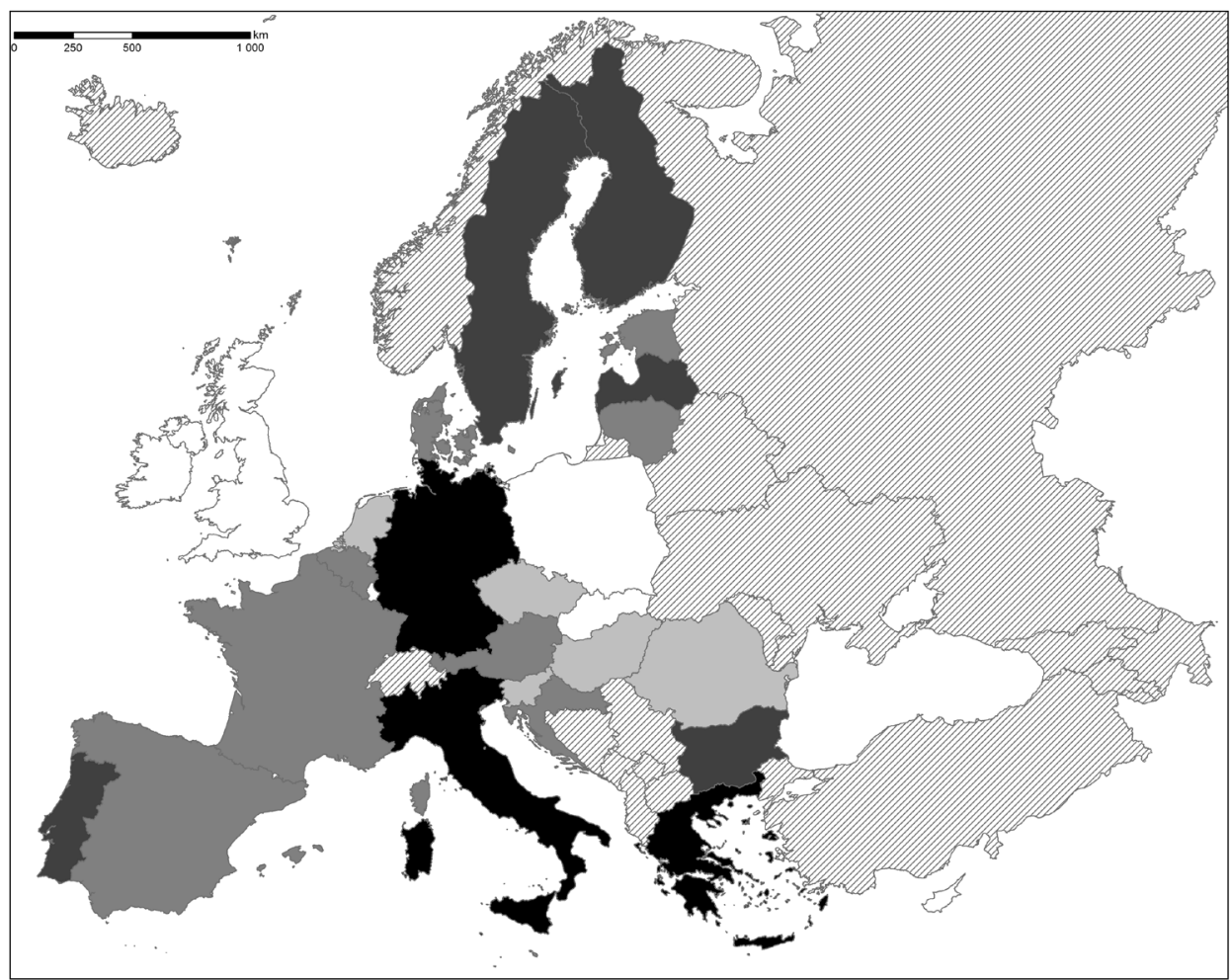

Odsetek ludności w wieku 65 lat i więcej

$\square 12,6-15,0 \square 15,1-17,5 \square 17,6-18,5 \square 18,6-20,0$

$20,1-21,4$

Rys. 2. Udział osób w wieku 65 lat i więcej w krajach UE 28 w 2014 roku Źródło: opracowanie własne na podstawie Eurostat, http://ec.europa.eu/eurostat/data/database

${ }^{1}$ Wyższą wartość ISD w 2014 roku odnotowała tylko Japonia - indeks starości demograficznej wyniósł 199 (http://databank.worldbank.org/data/reports.aspx?source=health-nutrition-and-population-statistics:-population-estimates-and-projections\#). 


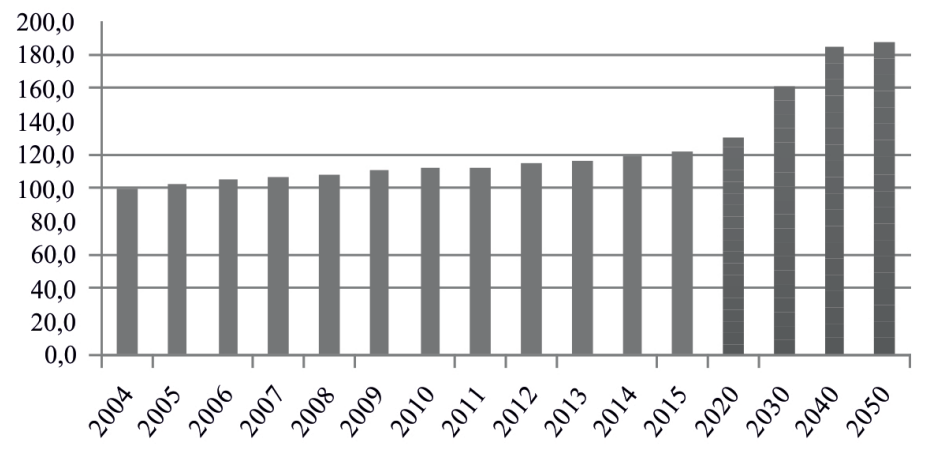

Rys. 3. Wartości indeksu starości demograficznej w UE 28 w latach 2004-2015

i prognozowany dla lat 2020-2050

Źródło: opracowanie własne na podstawie Eurostat, http://ec.europa.eu/eurostat/data/database

Jednym z czynników sprawczych wpływających bezpośrednio na starzenie się społeczeństw jest spadek poziomu płodności i rodności ${ }^{2}$. Jedną z miar opisujących przemiany w obszarze rodności jest współczynnik dzietności ogółem ${ }^{3}$ (TFR). Wartości tego współczynnika we wszystkich krajach UE 28 w 2014 roku nie przekroczyły 2,1 dziecka na kobietę, co gwarantowałoby zastępowalność pokoleń. Najbliżej tych wartości były Francja $(2,01)$, Irlandia $(1,94)$, Szwecja $(1,88)$ i Wielka Brytania (1,81). Najmniejsza dzietność wystąpiła w Portugalii $(1,23)$,

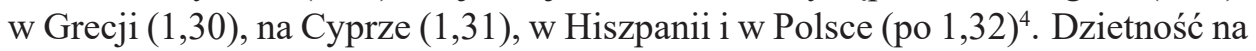
tak niskim poziomie przez wiele lat przyczyni się do: po pierwsze, zmniejszenia całkowitej populacji, po drugie, zmiany struktury demograficznej - kolejne pokolenia dzieci są bowiem o wiele mniej liczne od pokoleń ich rodziców.

2 Zachodzące współcześnie przemiany demograficznie dotyczą m.in. obszarów małżeńskości i rozrodczości. Zmiany modelu formowania się i rozpadu małżeństw oraz idące $\mathrm{z}$ nimi w parze przeobrażenia w sferze zachowań prokreacyjnych zaczęły się w latach 60 . $\mathrm{XX}$ wieku w wielu rozwiniętych krajach europejskich. Polska dołączyła do tych przemian trzydzieści lat później. Opisem wspomnianych zmian zajmuje się drugie przejście demograficzne. Według jednego z autorów tej koncepcji D. van de Kaa (1994), zmiany zachowań demograficznych obszaru małżeńskości i rozrodczości to wynik wpływu wielu czynników o charakterze społeczno-gospodarczym, politycznym, światopoglądowym oraz technologicznym.

3 Współczynnik dzietności ogółem oznacza liczbę dzieci, którą urodziłaby przeciętnie kobieta w ciągu całego okresu rozrodczego (15-49 lat) przy założeniu, że w poszczególnych fazach tego okresu rodziłaby $\mathrm{z}$ intensywnością obserwowaną $\mathrm{w}$ badanym roku, tzn. przy przyjęciu cząstkowych współczynników płodności z tego okresu za niezmienne (http://stat.gov.pl/obszary-tematyczne/zdrowie/zdrowie/zdrowie-kobiet-w-polsce-w-latach-2004-2009,9,1.html).

${ }^{4} \mathrm{http}: / /$ ec.europa.eu/eurostat/data/database. 
Wpływ umieralności na stopień i tempo starzenia się ludności może być dwojakiego rodzaju. W przypadku zwiększania się przeciętnej długości życia i zmniejszenia natężenia zgonów w starszych grupach wieku następuje starzenie się od wierzchołka piramidy wieku, powodujące zwiększanie się liczebności i udziałów roczników najstarszych. W społeczeństwach rozwiniętych oddziaływanie umieralności na starzenie się ludności odbywa się głównie poprzez zmniejszanie natężenia zgonów w starszych grupach wieku. Z drugiej strony, ukształtowana struktura wieku ludności o znamionach starości demograficznej „generuje” wysoki poziom umieralności $\mathrm{w}$ porównaniu z młodymi populacjami wskutek większego prawdopodobieństwa zgonów wśród osób starszych (Kurek 2008).

Jedną z konsekwencji starzenia się ludności są zmiany obciążenia demograficznego osób w wieku produkcyjnym dziećmi i młodzieżą oraz ludźmi starymi. Zdecydowana większość krajów UE odnotowała w latach 2004-2014 przyrost obciążenia ludności w wieku produkcyjnym ludnością w wieku nieprodukcyjnym (tab. 1). Tylko na Cyprze, w Luksemburgu i w Polsce zaznaczył się spadek wartości ogólnego współczynnika i był to wynik w większym stopniu zmian obciążenia ludzi w wieku 15-64 lata dziećmi i młodzieżą (zmniejszenie) niż obciążenia ludźmi starymi (gdzie odnotowano wzrost). W pozostałych 22 krajach (w Chorwacji nie zaobserwowano zmian) obciążenie ogólne wzrosło, głównie w wyniku wzrostu old dependency ratio (największy wzrost na Malcie - 7,4 i w Finlandii - 6,9).

Wśród krajów unijnych obciążenie ludności w wieku produkcyjnym ludźmi starymi w 2014 roku było największe we Włoszech, Grecji i Niemczech, na 100 osób w wieku produkcyjnym tych krajów przypadało adekwatnie 33,1, 31,6 i 31,5 osób w wieku 65 i więcej lat. W najmniejszym stopniu ludność w wieku 15-64 lata była obciążona osobami starszymi w Słowacji, Irlandii i na Cyprze, gdzie odnotowano najmniejsze wartości współczynnika old dependency ratio.

Tabela 1

Wartość współczynników obciążenia demograficznego w krajach UE 28 w 2014 roku i jego zmiany w latach 2004-2014

\begin{tabular}{|l|c|c|c|c|c|c|}
\hline \multirow{2}{*}{ Kraje } & \multicolumn{5}{|c|}{ Współczynniki obciążenia demograficznego } \\
\cline { 2 - 7 } & dziećmi i młodzieżą & \multicolumn{2}{|c|}{ ludźmi starymi } & \multicolumn{2}{c|}{ ogółem } \\
\cline { 2 - 7 } & wartość & $\begin{array}{c}\text { przyrost/ } \\
\text { ubytek } \\
(2004- \\
2014)\end{array}$ & wartość & $\begin{array}{c}\text { przyrost/ } \\
\text { ubytek } \\
(2004- \\
2014)\end{array}$ & wartość & $\begin{array}{c}\text { przyrost/ } \\
\text { ubytek } \\
(2004- \\
2014)\end{array}$ \\
\hline UE 28 & 23,7 & $-0,8$ & 28,1 & 3,8 & 51,8 & 3,1 \\
\hline Belgia & 26,1 & $-0,3$ & 27,3 & 1,2 & 53,4 & 0,9 \\
\hline Bułgaria & 20,6 & 0,1 & 29,3 & 4,2 & 50,0 & 4,3 \\
\hline Czechy & 22,2 & 0,7 & 25,7 & 6,0 & 47,9 & 6,7 \\
\hline
\end{tabular}


Tabela 1 (cd.)

\begin{tabular}{|c|c|c|c|c|c|c|}
\hline \multirow[b]{3}{*}{ Kraje } & \multicolumn{6}{|c|}{ Współczynniki obciążenia demograficznego } \\
\hline & \multicolumn{2}{|c|}{ dziećmi i młodzieżą } & \multicolumn{2}{|c|}{ ludźmi starymi } & \multicolumn{2}{|c|}{ ogółem } \\
\hline & wartość & $\begin{array}{c}\text { przyrost/ } \\
\text { ubytek } \\
(2004- \\
2014)\end{array}$ & wartość & $\begin{array}{c}\text { przyrost/ } \\
\text { ubytek } \\
(2004- \\
2014)\end{array}$ & wartość & $\begin{array}{c}\text { przyrost/ } \\
\text { ubytek } \\
(2004- \\
2014)\end{array}$ \\
\hline Dania & 26,7 & $-1,8$ & 28,3 & 5,8 & 54,9 & 3,9 \\
\hline Niemcy & 19,9 & $-1,9$ & 31,5 & 4,8 & 51,4 & 2,9 \\
\hline Estonia & 24,0 & 0,7 & 27,9 & 4,1 & 51,9 & 4,8 \\
\hline Irlandia & 33,6 & 2,9 & 19,3 & 3,0 & 52,9 & 5,8 \\
\hline Grecja & 22,6 & $-0,3$ & 31,6 & 4,5 & 54,2 & 4,2 \\
\hline Hiszpania & 22,8 & 1,7 & 27,2 & 2,8 & 50,0 & 4,5 \\
\hline Francja & 29,3 & 0,4 & 28,4 & 3,5 & 57,6 & 3,8 \\
\hline Chorwacja & 22,1 & $-2,1$ & 27,6 & 2,0 & 49,7 & 0,0 \\
\hline Włochy & 21,5 & 0,3 & 33,1 & 4,3 & 54,6 & 4,5 \\
\hline Cypr & 23,3 & $-6,8$ & 19,9 & 2,3 & 43,1 & $-4,6$ \\
\hline Łotwa & 22,2 & $-0,5$ & 28,8 & 5,0 & 51,0 & 4,5 \\
\hline Litwa & 21,8 & $-4,5$ & 27,5 & 4,5 & 49,4 & 0,1 \\
\hline Luksemburg & 24,4 & $-3,4$ & 20,4 & $-0,4$ & 44,7 & $-3,9$ \\
\hline Węgry & 21,2 & $-1,9$ & 25,8 & 3,2 & 47,0 & 1,3 \\
\hline Malta & 21,2 & $-5,3$ & 26,4 & 7,4 & 47,6 & 2,1 \\
\hline Holandia & 25,8 & $-1,6$ & 26,4 & 5,9 & 52,2 & 4,3 \\
\hline Austria & 21,3 & $-2,7$ & 27,2 & 4,5 & 48,4 & 1,7 \\
\hline Polska & 21,5 & $-3,2$ & 21,2 & 2,6 & 42,7 & $-0,6$ \\
\hline Portugalia & 22,3 & $-1,6$ & 30,3 & 5,0 & 52,5 & 3,3 \\
\hline Rumunia & 22,8 & $-2,8$ & 24,3 & 3,6 & 47,1 & 0,8 \\
\hline Słowenia & 21,5 & 0,7 & 25,7 & 4,3 & 47,2 & 5,1 \\
\hline Słowacja & 21,5 & $-3,3$ & 19,0 & 2,7 & 40,6 & $-0,5$ \\
\hline Finlandia & 25,6 & $-0,8$ & 30,2 & 6,9 & 55,8 & 6,1 \\
\hline Szwecja & 26,9 & $-0,5$ & 30,6 & 4,2 & 57,4 & 3,6 \\
\hline $\begin{array}{l}\text { Wielka } \\
\text { Brytania }\end{array}$ & 27,2 & $-0,7$ & 27,0 & 2,8 & 54,2 & 2,1 \\
\hline
\end{tabular}

Źródło: Eurostat, http://ec.europa.eu/eurostat/data/database. 


\subsection{STAN ZDROWIA OSÓB 65+ W KRAJACH UNIJNYCH I JEGO SUBIEKTYWNA OCENA}

W wydanych, w ostatnich dwóch dekadach, dokumentach międzynarodowych (np. opublikowane przez WHO: Zdrowie dla wszystkich w 2000 roku 1984; Karta Ottawska 1986; Światowa Deklaracja Zdrowia 1998; ŚOZ - Zdrowie 21 - zdrowie dla wszystkich w XXI wieku 1999) podkreśla się, że zdrowie jest:

- wartością dla jednostki - warunkiem wstępnym dla dobrego samopoczucia i odpowiedniej jakości życia (rozumianej jako sprawne funkcjonowanie do późnej starości, umożliwiające większą wydajność w pracy i lepsze zarobki oraz satysfakcję z życia),

- podstawowym prawem każdego człowieka,

- zasobem (bogactwem) dla społeczeństwa - tylko zdrowe społeczeństwo może tworzyć dobra materialne i kulturowe, rozwijać się,

- podstawą zrównoważonego rozwoju społecznego i gospodarczego Państwa (dobre zdrowie obywateli).

W krajach rozwiniętych gospodarczo starość wpisana jest w społeczno-ekologiczny model zdrowia, którego celem jest ocena globalnej jakości życia, łącząca medyczne, psychospołeczne i kulturowe jego aspekty. Podnoszenie standardu życia ludzi starszych stało się kluczowym projektem starzejących się społeczeństw cywilizacji zachodniej (Czarnecka 2004). Podejmowane są działania zmierzające do podnoszenia jakości życia ludzi starych w różnych sferach życia. Według M. Gałuszki (2006) występuje wielu obszarów refleksji i działań na rzecz poprawy jakości życia ludzi starszych. Zalicza do nich:

- rekomendacje zintegrowanej polityki społecznej i zdrowotnej, dla której zdrowie ludzi starszych stało się celem,

- wzrost standardu opieki medycznej i powstawanie wysoko specjalistycznych procedur usług medycznych dla ludzi starszych,

- dynamiczny rozwój rynku usług i produktów ,populacji siwych” i wzrost zasobów finansowych seniorów,

- wypracowanie przez kulturę i media masowe nowego wizerunku starości akcentującego witalność i możliwości konsumpcyjne seniorów,

- tworzenie nowych regulacji prawnych broniących interesów populacji ludzi starszych,

- podejmowanie badań naukowych i pogłębionych refleksji etyczno-religijnych;

- formułowanie różnych systemów ewaluacji jakości życia seniorów i związanych z tą oceną procedur wsparcia instytucjonalnego.

W Strategii Zdrowie 21 - zdrowie dla wszystkich w XXI wieku Światowej Organizacji Zdrowia dla Regionu Europejskiego określającej kierunki polityki zdrowotnej, pojawiają się wielowymiarowe ujęcia zdrowia odniesione także do 
ludzi starszych. Podkreśla się potrzebę subiektywnego odczuwania satysfakcji ze swojego pełnego potencjału zdrowotnego i pełnienia aktywnego życia społecznego. Obiektywne wskaźniki pokazują kierunki pożądanych zmian i nałożone cele: „Wzrost przynajmniej o 20\% oczekiwanej długości życia oraz wydłużenie oczekiwanego życia bez niepełnosprawności do 65 lat” oraz wzrost „,przynajmniej o $50 \%$ odsetka ludzi w wieku 80 lat cieszących się takim poziomem zdrowia w otoczeniu domowym, który pozwala na zachowanie samodzielności, poczucia własnej godności i swojego miejsca w społeczeństwie" (Zdrowie... 2001, s. 75).

Biorąc pod uwagę przeciętną długość trwania życia, jako ogólny wskaźnik zdrowia społeczeństw, należy podkreślić, że jest ona zróżnicowana ze względu na płeć. Długość życia kobiet jest dłuższa o kilka lat we wszystkich krajach Europy i w zdecydowanej większości pozostałych krajów świata ${ }^{5}$. W całej Unii dystans między długością życia kobiet i mężczyzn wyniósł w 2014 roku ponad 4 lata (tab. 2). Najdłuższe trwanie życia w przypadku mężczyzn wystąpiło na Cyprze (80,9 lat), a największa długość życia kobiet we Francji (86 lat). Najkrócej, według tablic trwania życia, żyli mężczyźni na Łotwie $(69,1$ lat) i kobiety w Bułgarii (78,0 lat). W Polsce wartości trwania życia zarówno mężczyzn (73,7 lat), jak i kobiet (81,7 lat) były niższe od średniej unijnej. Wśród krajów unijnych największe różnice w długości życia obu subpopulacji reprezentowały kraje nadbałtyckie - Litwa (10,9 roku), Lotwa (10,3 roku) i Estonia (9,5 roku), zaś najmniejsze były w Holandii (3,5 roku). Tak wysokie różnice w długości życia pomiędzy kobietami i mężczyznami w krajach postradzieckich to wynik największego w Europie poziomu nadumieralności mężczyzn. Główną grupą chorób powodującą tak duże różnice była nadumieralność z powodu zewnętrznych przyczyn, urazów i zatruć. O ile w przypadku wczesnej nadumieralności mężczyzn występowała ich wyraźna dominacja, o tyle w przypadku późnej znaczenia nabierały także nadumieralność z powodu chorób układu krążenia i nowotworów (Michalski 2010, 2012).

Nieco inaczej kształtowały się wśród krajów UE 28 wartości długości życia osób odmiennej płci powyżej 65. roku życia. Najkrótsza przewidywana długość życia osób starych wystąpiła w Bułgarii (mężczyźni - 14,1 lat, kobiety - 17,6 lat), a najlepsza sytuacja była we Francji, gdzie dla obu subpopulacji seniorów trwanie długości życia było największe (mężczyźni - 19,7 lat, kobiety - 24,0 lat). Różnice w długości trwania życia pomiędzy mężczyznami i kobietami w wieku $65+$ były także największe w krajach nadbałtyckich, dla Litwy, Łotwy i Estonii - wyniosły po 5,2 roku. Najmniejsza rozbieżność w długości trwania życia osób w wieku podeszłym wystąpiła w 2014 roku na Cyprze i w Wielkiej Brytanii - różnice pomiędzy mężczyznami i kobietami wyniosły po 2,5 roku (tab. 2).

${ }^{5}$ Tylko w Mali i Suazi trwanie życia mężczyzn było dłuższe niż kobiet, w Mali o 0,4 roku, w Suazi o 0,2 roku (Demographic Yearbook, 2014, http://unstats.un.org/unsd/ demographic/products/dyb/dyb2014.htm). 
Tabela 2

Przeciętne trwanie życia mieszkańców UE 28 w 2014 roku

\begin{tabular}{|c|c|c|c|c|}
\hline \multirow[t]{2}{*}{ Kraj } & \multicolumn{2}{|c|}{$\begin{array}{c}\text { Przeciętne trwanie życia } \\
\text { nowowrodka }\end{array}$} & \multicolumn{2}{|c|}{$\begin{array}{l}\text { Przeciętne trwanie życia } \\
\text { w wieku } 65 \text { lat i więcej }\end{array}$} \\
\hline & mężczyźni & kobiety & mężczyźni & kobiety \\
\hline UE 28 & 78,1 & 83,6 & 18,2 & 21,6 \\
\hline Belgia & 78,8 & 83,9 & 18,4 & 21,9 \\
\hline Bułgaria & 71,1 & 78,0 & 14,1 & 17,6 \\
\hline Czechy & 75,8 & 82,0 & 16,1 & 19,8 \\
\hline Dania & 78,7 & 82,8 & 18,1 & 20,8 \\
\hline Niemcy & 78,7 & 83,6 & 18,2 & 21,4 \\
\hline Estonia & 72,4 & 81,9 & 15,2 & 20,4 \\
\hline Irlandia & 79,3 & 83,5 & 18,4 & 21,1 \\
\hline Grecja & 78,9 & 84,1 & 18,8 & 21,6 \\
\hline Hiszpania & 80,4 & 86,2 & 19,3 & 23,5 \\
\hline Francja & 79,5 & 86,0 & 19,7 & 24,0 \\
\hline Chorwacja & 74,7 & 81,0 & 15,5 & 19,1 \\
\hline Włochy & 80,7 & 85,6 & 19,2 & 22,8 \\
\hline Cypr & 80,9 & 84,7 & 18,9 & 21,4 \\
\hline Łotwa & 69,1 & 79,4 & 13,8 & 19,0 \\
\hline Litwa & 69,2 & 80,1 & 14,3 & 19,5 \\
\hline Luksemburg & 79,4 & 85,2 & 18,4 & 22,7 \\
\hline Węgry & 72,3 & 79,4 & 14,6 & 18,6 \\
\hline Malta & 79,8 & 84,2 & 18,6 & 21,7 \\
\hline Holandia & 80,0 & 83,5 & 18,6 & 21,4 \\
\hline Austria & 79,1 & 84,0 & 18,5 & 21,8 \\
\hline Polska & 73,7 & 81,7 & 15,9 & 20,4 \\
\hline Portugalia & 78,0 & 84,4 & 18,1 & 21,9 \\
\hline Rumunia & 71,4 & 78,7 & 14,7 & 18,1 \\
\hline Słowenia & 78,2 & 84,1 & 17,7 & 21,6 \\
\hline Słowacja & 73,3 & 80,5 & 15,1 & 19,1 \\
\hline Finlandia & 78,4 & 84,1 & 18,2 & 21,7 \\
\hline Szwecja & 80,4 & 84,2 & 18,9 & 21,6 \\
\hline Wielka Brytania & 79,5 & 83,2 & 18,8 & 21,3 \\
\hline
\end{tabular}

Źródło: Eurostat, http://ec.europa.eu/eurostat/data/database. 
Przeciętne dalsze trwanie życia noworodka jest szeroko używanym wskaźnikiem stanu zdrowia populacji, jednak jej znajomość nie pozwala wyciągnąć wniosków na temat jakości życia (Burzyńska i in. 2010). Nowe mierniki zdrowia wykraczające poza negatywne wskaźniki dotyczące umieralności i trwania życia, obejmują także inne wymiary stanu zdrowia i jakości życia powiązanej ze zdrowiem. Nazywane są one sumarycznymi miarami stanu zdrowia (summary measures of population health). Wskaźniki te można podzielić na dwie zasadnicze grupy: miary oczekiwanego zdrowia i miary braku zdrowia. Pierwsza grupa pozwala na określenie lat życia przeżytych w pełnym zdrowiu oraz lat przeżytych z pewnymi dysfunkcjami i niesprawnością jako równoważnik tych pierwszych (Wróblewska 2008). Należą do nich m.in.:

- oczekiwana długość życia bez niesprawności (Disability Free Life Expectancy

- DFLE)/oczekiwane lata życia w zdrowiu (Healthy Life Years - HLY),

- oczekiwana długość trwania życia skorygowana jakością (Qualityadjusted Life Expectancy - QALE),

- oczekiwana długość trwania życia w aktywności (Active Life Expectance-ALE),

- oczekiwana długość trwania życia bez chorób przewlekłych,

- oczekiwana długość trwania życia skorygowana ze względu na niesprawność

(Disability-adjusted Life Expectancy - DALE)/oczekiwana długość życia skorygowana ze względu na stan zdrowia (Healthy Life Expectancy - HALE).

Oczekiwana długość życia bez niesprawności (DFLE) została zaproponowana jako jeden ze wskaźników monitorujących stan zdrowia w krajach europejskich, a w roku 1993 Organizacja Współpracy Gospodarczej i Rozwoju włączyła tę miarę do wskaźników zdrowia liczonych dla krajów OECD. Od 2004 roku wskaźniki te publikowane są pod nazwą , lata życia w zdrowiu” (HLY) i opracowywane są przez Eurostat dla krajów Unii Europejskiej (Wróblewska 2008). Wskaźnik lat zdrowego życia określa dwie cechy populacji - długość życia i jakość życia w odniesieniu do zdrowia. Wskaźnik lat przeżytych w zdrowiu opracowano na podstawie obserwacji, że nie wszystkie lata określane przez oczekiwaną długość życia są przeżywane w pełnym zdrowiu. To, że daną populację cechuje wysoki współczynnik oczekiwanej długości życia, nie znaczy, że populacja ta jest zdrowa.

Jak wcześniej pisano, przeciętne trwanie życia kobiet jest dłuższe niż mężczyzn we wszystkich krajach unijnych, zarówno w chwili urodzenia, jak i w wieku 65 lat i więcej. Długość życia w zdrowiu mieszkańców Unii powyżej 65. roku życia jest w większym stopniu zróżnicowana przestrzennie. Bowiem w 13 krajach UE mężczyźni cieszą się dłuższym życiem w zdrowiu niż kobiety, w Belgii i Litwie nie ma żadnej różnicy, a w pozostałych krajach (13) to kobiety żyją dłużej w zdrowiu (rys. 4). Największa przewaga w długości życia w zdrowiu osób powyżej 65. roku życia na korzyść mężczyzn wystąpiła na Cyprze (1,6 roku) i w Portugalii (1,3 roku), a w przypadku kobiet były to Dania (1,8 roku) i Szwecja (1,5 roku). 


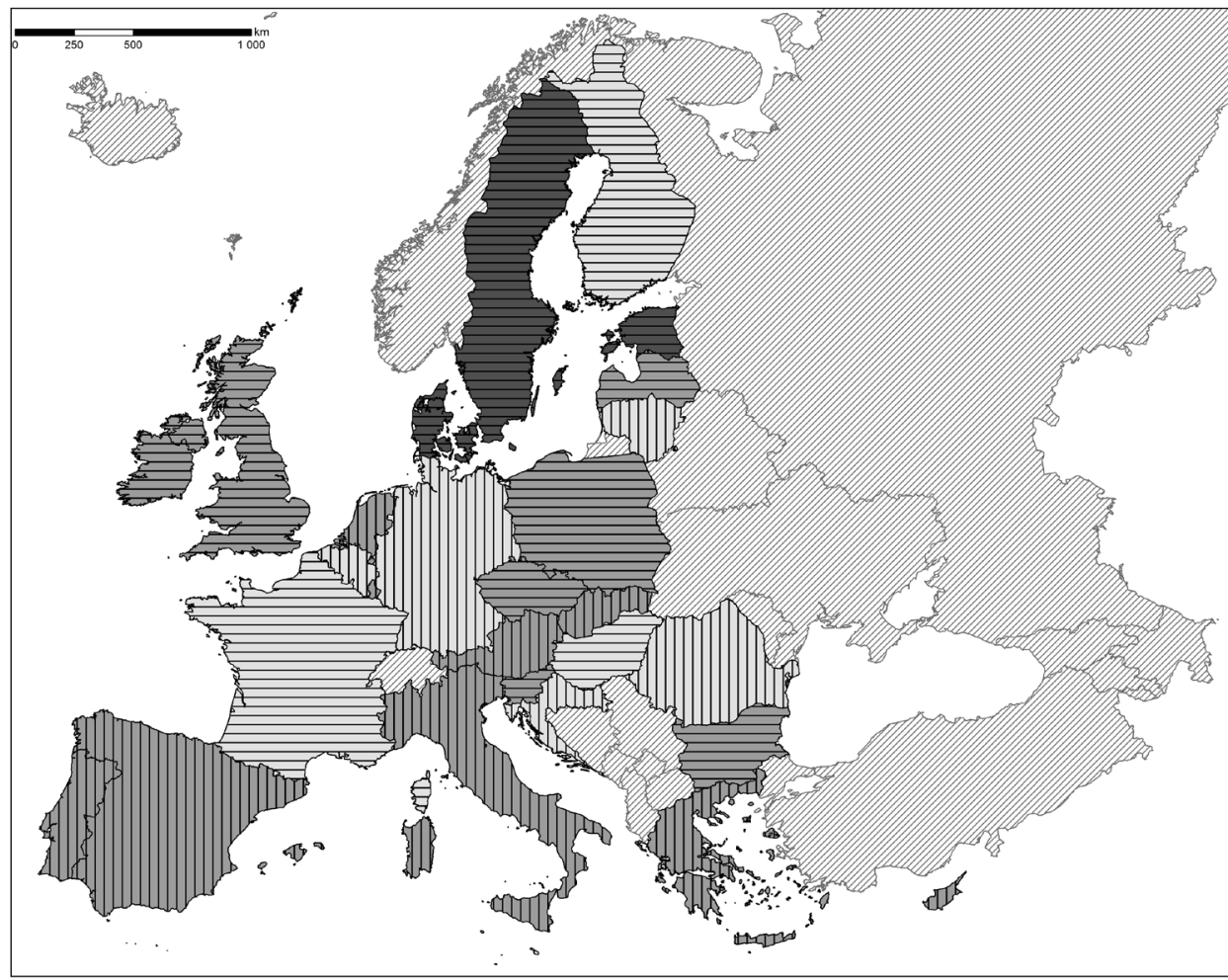

Różnica długości życia w zdrowiu kobiet i mężczyzn w wieku 65 lat i więcej (wiek kobiet - wiek mężczyzn w latach)

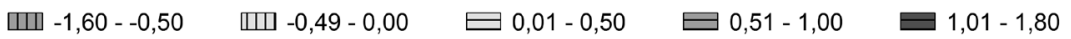

Rys. 4. Różnica długości życia w zdrowiu kobiet i mężczyzn w wieku 65 lat i więcej w krajach UE 28 w 2014 roku

Źródło: opracowanie własne na podstawie Eurostat, http://ec.europa.eu/eurostat/data/database

Na jakość życia osób starszych wpływa ich stan zdrowia, czyli długość życia w dobrej kondycji fizycznej i psychicznej. W tym przypadku dywersyfikacja przestrzenna w krajach Unii w 2014 roku była bardzo duża. Największym odsetkiem długości życia w zdrowiu w długości życia osób w wieku 65 lat i więcej mogli poszczycić się Szwedzi (80,4\%) i Szwedki (77,3\%). Z danych Eurostatu wynika, że najgorszy stan zdrowia osób starych występuje w Słowacji, ponieważ długość życia w zdrowiu stanowiła zaledwie 19\% długości życia kobiet i 28,2\% mężczyzn powyżej 65. roku życia (rys. 5, 6). 


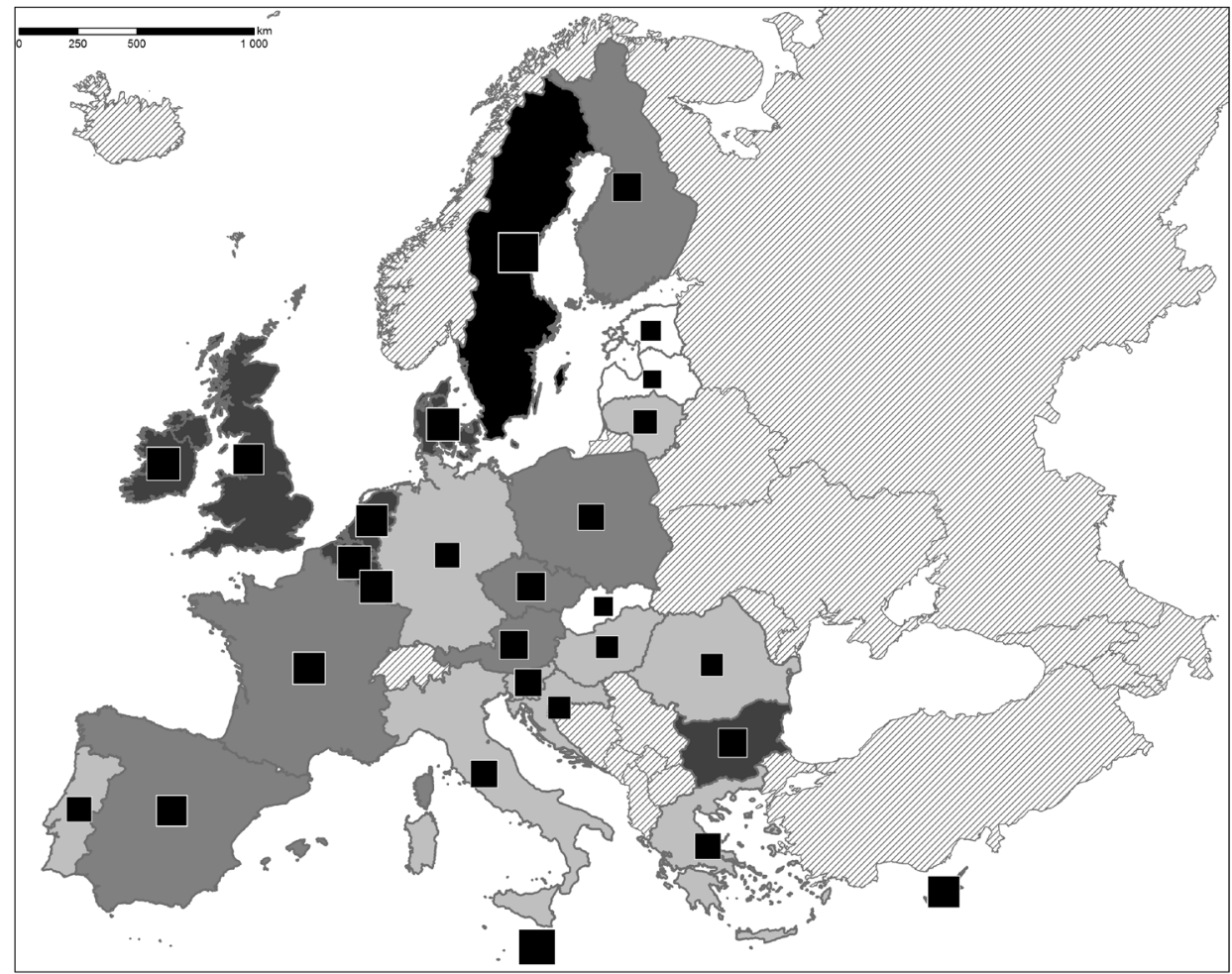

Odsetek długości życia w zdrowiu w długości życia mężczyzn w wieku 65 lat i więcej (\%)

$\square 28,2-35,0 \square 35,1-45,0 \square 45,1-55,0 \square 55,1-65,0 \square$ 65,1-80,4

- $1 \square 5 \square 10$ Długość życia w zdrowiu mężczyzn w wieku 65 lat i więcej (lata)

Rys. 5. Długość życia w zdrowiu mężczyzn w wieku 65 lat i więcej w krajach UE 28 w 2014 roku

Źródło: opracowanie własne na podstawie Eurostat, http://ec.europa.eu/eurostat/data/database

W ramach systemu statystycznego służącego do monitorowania zdrowia ludności krajów unijnych przeprowadzane są European Health Interview Survey (EHIS) ${ }^{6}$. Europejskie Ankietowe Badanie Zdrowia z 2014 roku obejmowało cztery obszary tematyczne:

${ }^{6}$ Realizacja badania stanowiła wykonanie zadań określonych w Rozporządzeniu Parlamentu Europejskiego i Rady w sprawie statystyk Wspólnoty w zakresie zdrowia publicznego oraz zdrowia i bezpieczeństwa w pracy Nr 1338/2008. Eurostat przygotował jednolite narzędzia badawcze (tj. treść pytań i warianty odpowiedzi) oraz wytyczne dotyczące wymagań, jakie powinno spełnić każde badanie krajowe. Zadaniem krajów członkowskich było natomiast opracowanie wersji narodowych poszczególnych modułów oraz ich wdrożenie zgodnie z określonym harmonogramem, z zachowaniem zaleceń metodologicznych i logistyki organizacji badania (Stan zdrowia ludności Polski 2009, 2011, GUS, Warszawa). 
- stan zdrowia (samoocena stanu zdrowia, choroby przewlekłe, ograniczenia w funkcjonowaniu i ich wpływ na życie codzienne, wypadki, samopoczucie psychiczne),

- opieka zdrowotna (korzystanie z opieki medycznej, stosowanie leków, profilaktyka),

- determinanty zdrowia (głównie styl życia),

- charakterystyka demograficzno-społeczna osób i gospodarstw domowych.

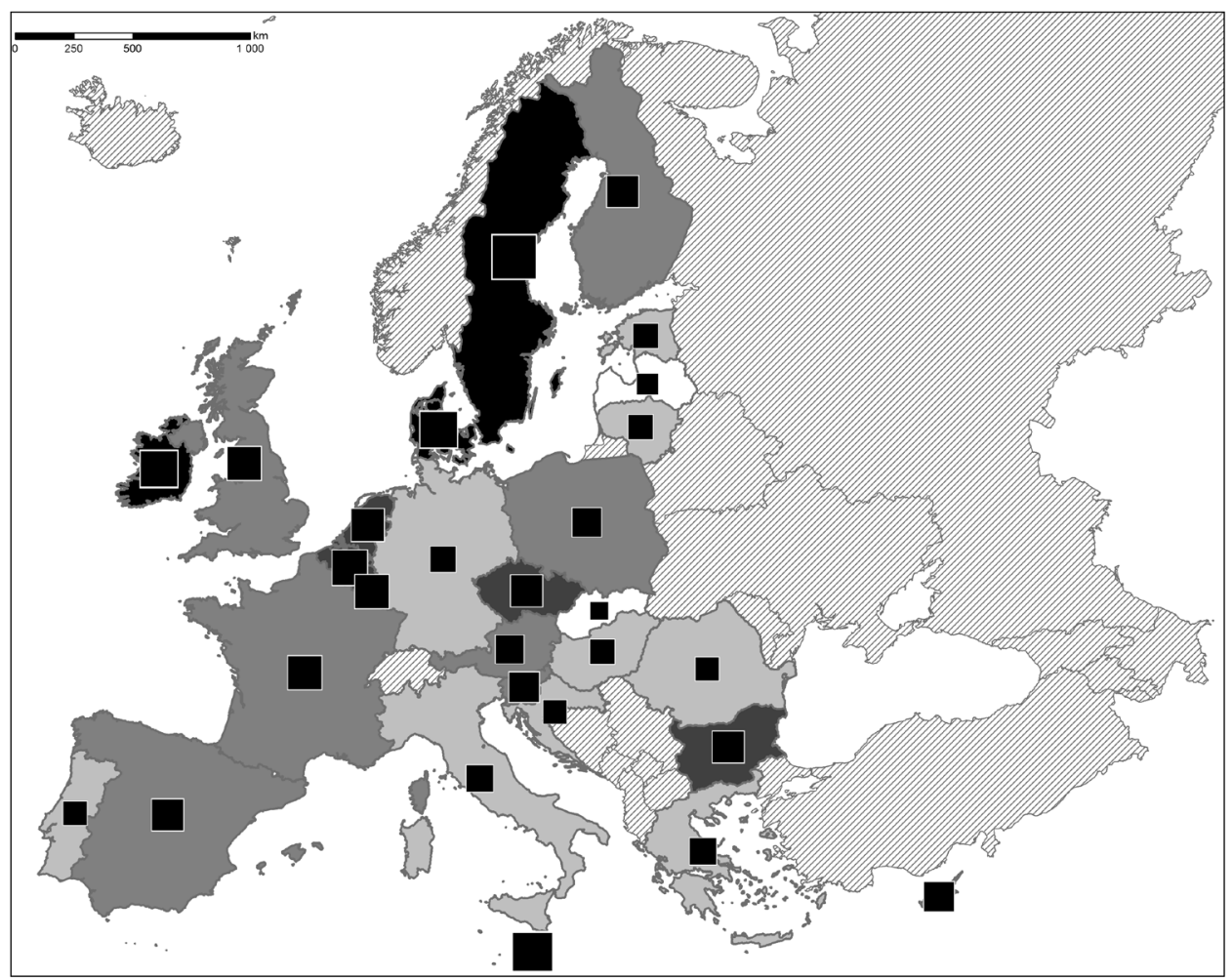

Odsetek długości życia w zdrowiu w długości życia kobiet w wieku 65 lat i więcej (\%)

$\square$ 19,0-25,0 $\square 25,1-35,0 \square 35,1-45,0 \square 45,1-55,0 \square 55,1-77,3$

- $1 \square 5 \square 10$ Długość życia w zdrowiu kobiet w wieku 65 lat i więcej (lata)

Rys. 6. Długość życia w zdrowiu kobiet w wieku 65 lat i więcej

w krajach UE 28 w 2014 roku

Źródło: opracowanie własne na podstawie Eurostat, http://ec.europa.eu/eurostat/data/database

Mieszkańcy Unii, dokonując subiektywnej oceny stanu swojego zdrowia, mieli możliwość dokonania wyboru z pięciu możliwych alternatyw (oceny: bardzo dobra, dobra, średnia, zła i bardzo zła). Samoocena stanu zdrowia była 
zróżnicowana przede wszystkim ze względu na płeć respondentów biorących udział w EHIS. W całej Unii lepiej swój stan zdrowia oceniali mężczyźni, ponad $41 \%$ z nich określiło, że jest on dobry lub bardzo dobry, podczas gdy mieszkanki krajów unijnych wystawiły mniej takich ocen o blisko 7\%. Więcej ocen pozytywnych swojego stanu zdrowia ze strony mężczyzn odnotowano we wszystkich krajach unijnych z wyjątkiem Wielkiej Brytanii (więcej ocen pozytywnych ze strony kobiet), choć tu różnica nie była duża - wyniosła 1,6\%. Największy dysonans w subiektywnych ocenach stanu zdrowia pomiędzy mężczyznami i kobietami wystąpił na Cyprze (14,2\%), w Hiszpanii (13,0\%) i w Rumunii (10,5\%), a najmniejszy w Finlandii $(0,9 \%)$ - rys. $7,8$.

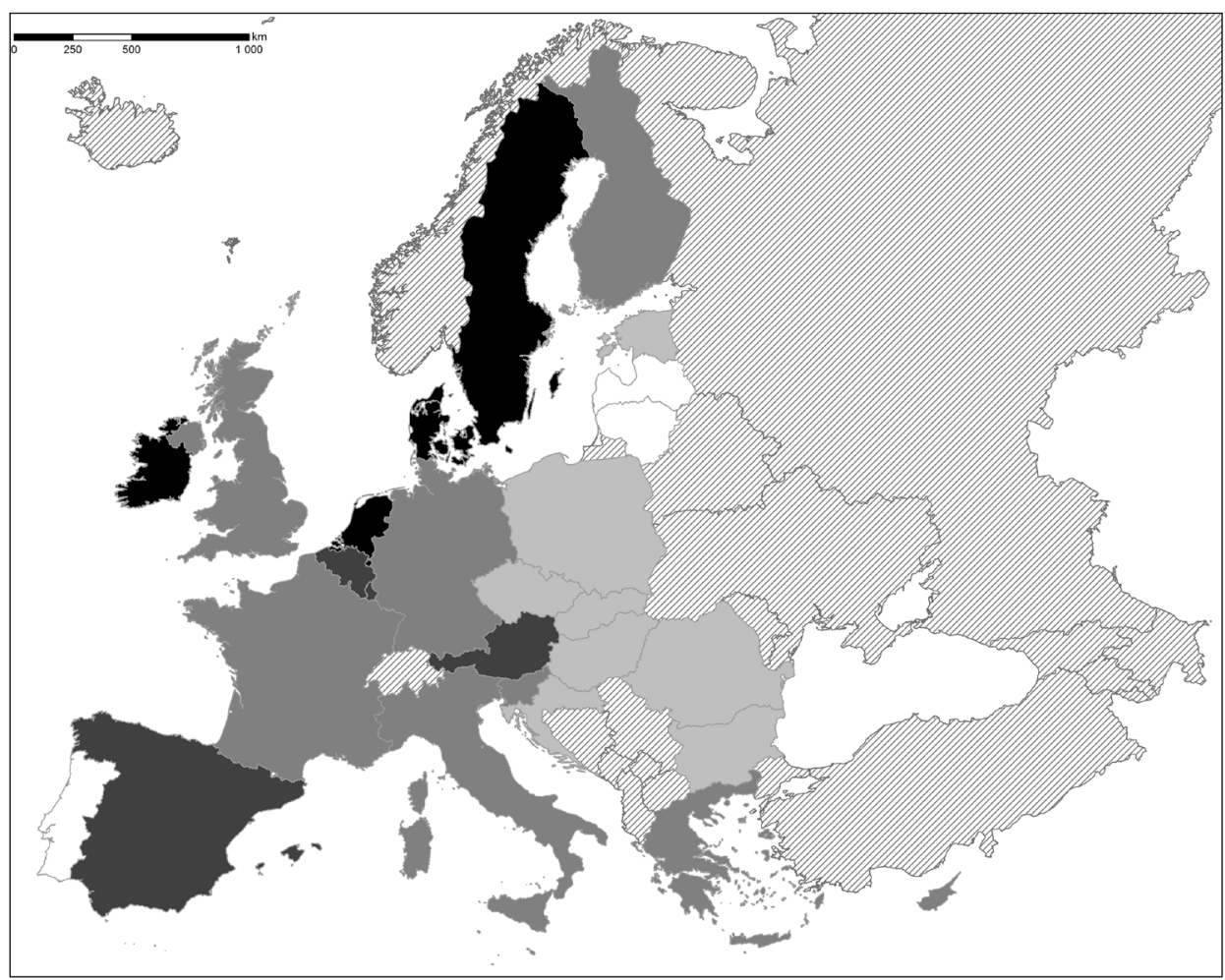

Samoocena stanu zdrowia mężczyzn w wieku 65 lat i więcej - ocena dobra i bardzo dobra

$\square$ 6,2-15,0 $\square$ 15,1-30,0 $\square 30,1-45,0 \square$ 45,1-60,0 $60,1-71,5$

Rys. 7. Subiektywna ocena stanu zdrowia mężczyzn w wieku 65 lat i więcej w krajach UE 28 w 2014 roku - ocena dobra i bardzo dobra (\%)

Źródło: opracowanie własne na podstawie Eurostat, http://ec.europa.eu/eurostat/data/database 


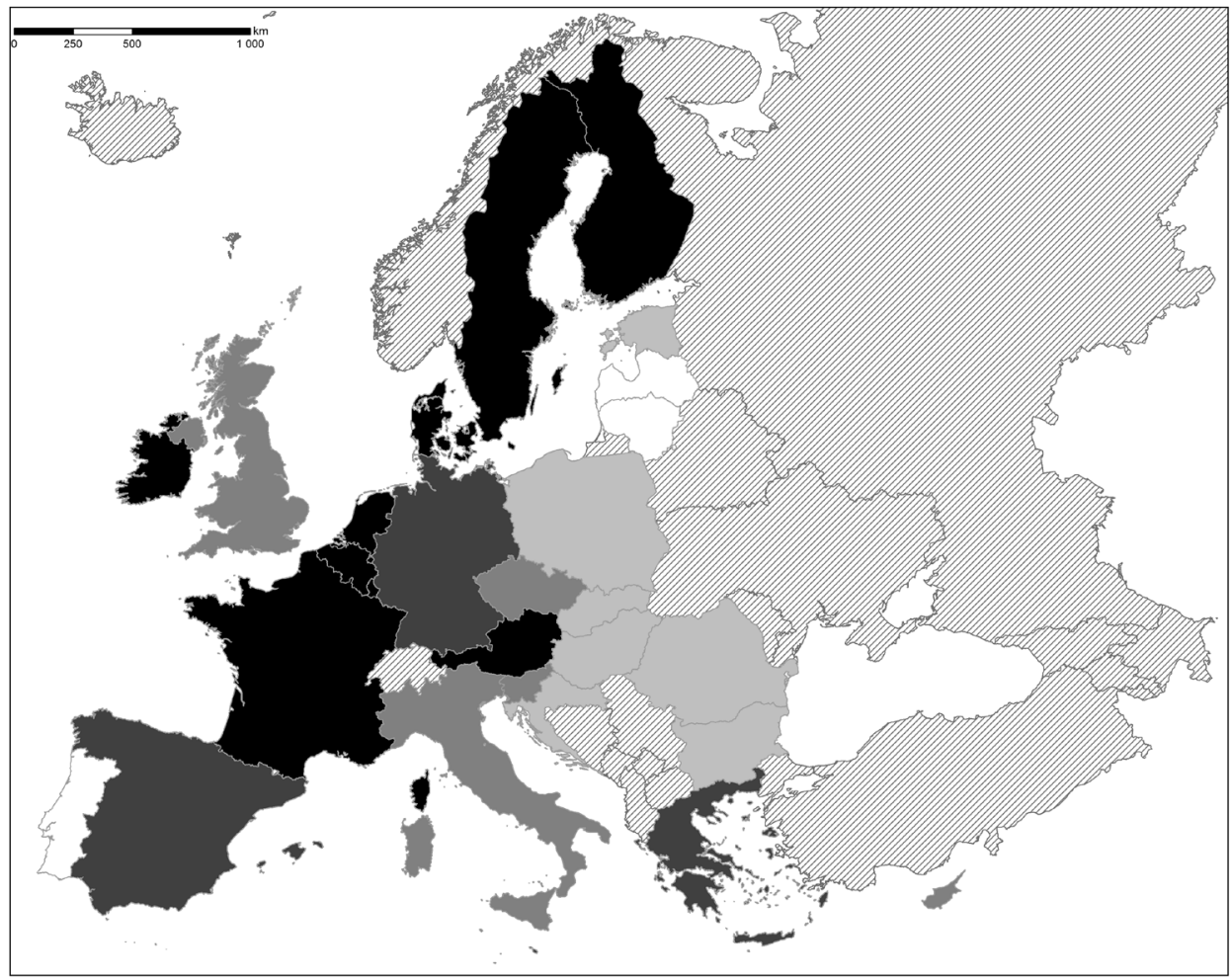

Samoocena stanu zdrowia kobiet w wieku 65 lat i więcej - ocena dobra i bardzo dobra

$\square 3,1-10,0 \square 10,1-20,0 \square 20,1-30,0 \square 30,1-40,0 \square 40,1-64,5$

Rys. 8. Subiektywna ocena stanu zdrowia kobiet w wieku 65 lat i więcej w krajach UE 28 w 2014 roku - ocena dobra i bardzo dobra (\%)

Źródło: opracowanie własne na podstawie Eurostat, http://ec.europa.eu/eurostat/data/database

Najlepiej swój stan zdrowia oceniali mieszkańcy Szwecji (zarówno mężczyźni jak i kobiety), ponad 71\% Szwedów i 64\% Szwedek oceniło stan swojego zdrowia jako dobry i bardzo dobry. Bardzo wysokie subiektywne oceny stanu zdrowia odnotowano także w Holandii, Irlandii i Danii. Krajami, w których był najmniejszy odsetek osób oceniających wysoko swój stan zdrowia były Litwa i Łotwa. Wśród mieszkańców Litwy udział ocen dobrych i bardzo dobrych swojego stanu zdrowia wyniósł dla mężczyzn - 6,2\%, dla kobiet - 3,1\%, na Lotwie wartości te były nieznacznie wyższe, adekwatnie: 8,9\% i 8\%. W Polsce zadowolenie ze stanu swojego zdrowia osób 65+ także nie było wysokie, o czym świadczą odsetki przypisanych ocen dobrych i bardzo dobrych - 18,5\% mężczyźni i 13,1\% kobiety.

Różnice pomiędzy płciami w wyrażaniu zdania na temat swojego stanu zdrowia osób starych ujawniły się również przy ocenach negatywnych, w tym przy- 
padku więcej takich ocen przypisywały kobiety. Wśród mężczyzn Unii Europejskiej zarejestrowano blisko $20 \%$ złych i bardzo złych ocen stanu zdrowia, a po stronie kobiet było to ponad $24 \%$. Najgorzej ocenili swoje zdrowie Chorwaci i Litwini (rys. 9, 10). Ponad połowa ankietowanych Chorwatek i Litwinek oraz ponad $40 \%$ mężczyzn z tych krajów oceniło negatywnie stan swojego zdrowia. Najmniej ocen negatywnych swojej kondycji zdrowotnej przydzielili Szwedzi, Irlandczycy, Holendrzy i Duńczycy, którzy jednocześnie, o czym pisano wyżej, wystawili najlepsze oceny swojego stanu zdrowia.

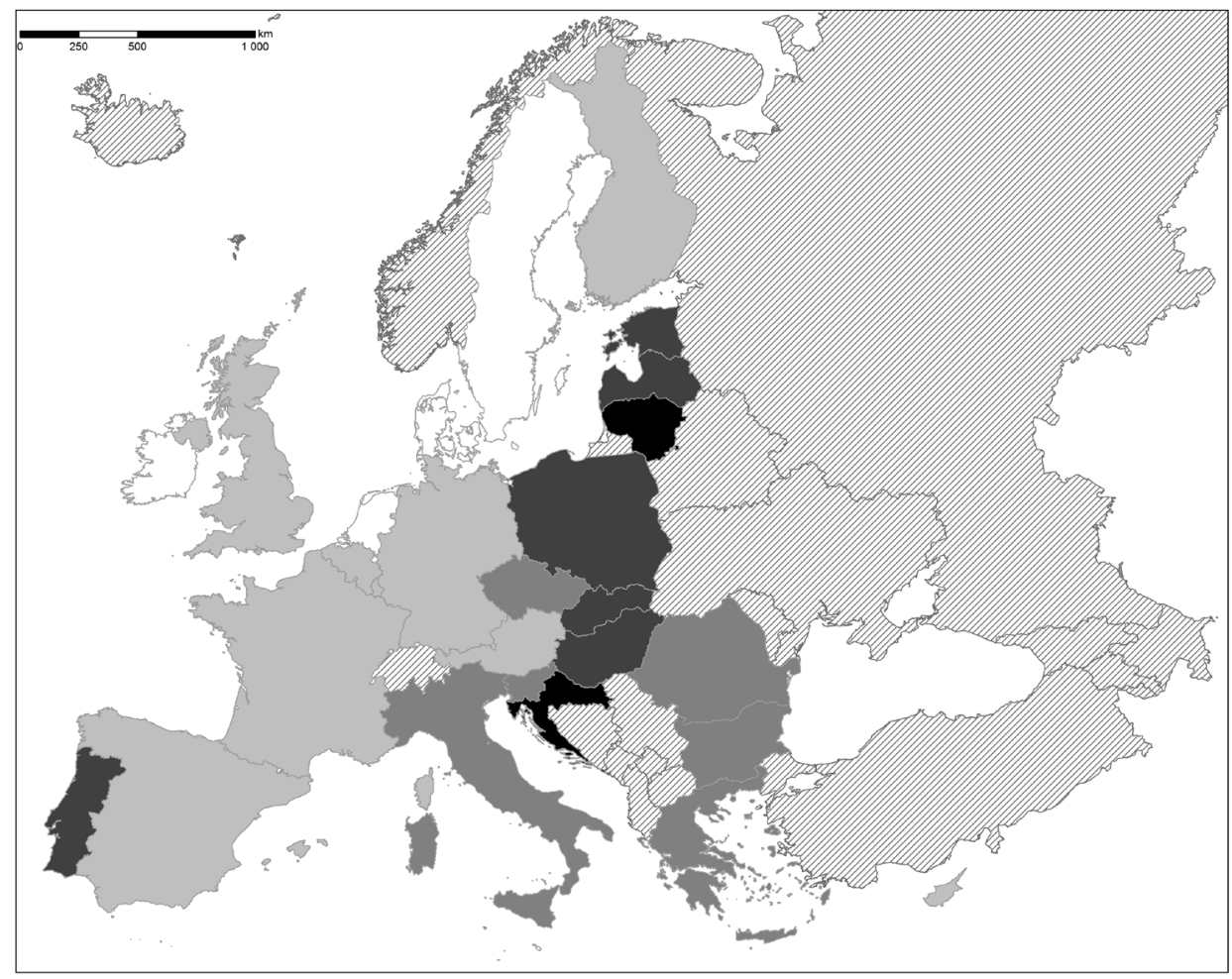

Samoocena stanu zdrowia mężczyzn w wieku 65 lat i więcej - ocena zła i bardzo zła

$\square$ 5,4-10,0 $\square$ 10,1-20,0 $\square$ 20,1-30,0 $\quad$ 30,1-40,0 $40,1-4,8$

Rys. 9. Subiektywna ocena stanu zdrowia mężczyzn w wieku 65 lat i więcej w krajach UE 28 w 2014 roku - ocena zła i bardzo zła (\%)

Źródło: opracowanie własne na podstawie Eurostat, http://ec.europa.eu/eurostat/data/database

Odmienne postawy mężczyzn i kobiet wobec postrzegania swojej kondycji zdrowotnej wystąpiły we wszystkich krajach Unii, z wyjątkiem Wielkiej Brytanii, gdzie to kobiety przypisały mniej ocen negatywnych, ale różnica była niewielka 


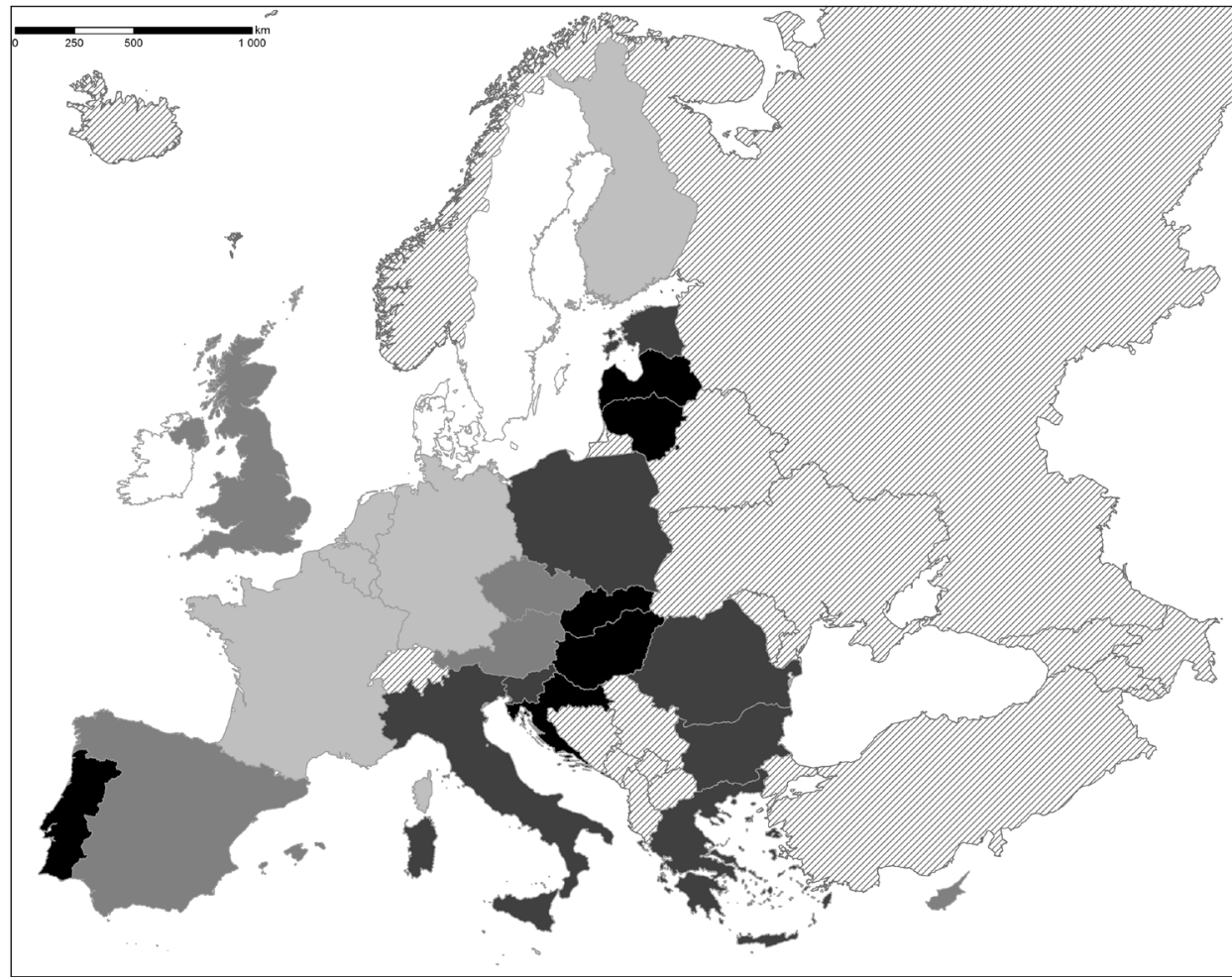

Samoocena stanu zdrowia kobiet w wieku 65 lat i więcej - ocena zła i bardzo zła

$\square 7,4-10,0 \square 10,1-20,0 \square 20,1-30,0 \square 30,1-40,0 \square 40,1-53,2$

Rys. 10. Subiektywna ocena stanu zdrowia kobiet w wieku 65 lat i więcej w krajach UE 28 w 2014 roku - ocena zła i bardzo zła (\%)

Źródło: opracowanie własne na podstawie Eurostat, http://ec.europa.eu/eurostat/data/database

i wyniosła zaledwie 0,5\%. Największe dysproporcje płciowe w wyrażaniu opinii dotyczących postaw wobec zdrowia wystąpiły w Chorwacji, różnica wyniosła blisko 15\%.

Z przeprowadzonej analizy wynika, że płeć można uznać jako jeden z istotnych wyznaczników nierówności w stanie zdrowia pomiędzy kobietami a mężczyznami, należy przy tym zwrócić uwagę na dwa typy zależności. Pierwszy odpowiada zróżnicowaniu wynikającemu z przyczyn biologicznych ${ }^{7}$ (sex), drugi natomiast -

${ }^{7} \mathrm{~W}$ literaturze naukowej wyjaśnia się np. różnicę $\mathrm{w}$ umieralności niemowląt $\mathrm{z}$ perspektywy płci biologicznej. Różnice genetyczne między płcią żeńską i męską mają wpływ na większą umieralność niemowląt i noworodków płci męskiej. Płeć męska od żeńskiej różni się składem chromosomów. Jedna para z 23 par chromosomów determinuje płeć męską (XY), natomiast aby płeć dziecka była żeńska, musi wystąpić para chromosomów $\mathrm{XX}$. Chromosom X zawiera więcej informacji genetycznych od chromosomu Y, również 
ze społeczno-kulturowych (gender). Obok przyczyn biologicznych wynikających z płci biologicznej, nierówności w stanie zdrowia pomiędzy kobietami a mężczyznami biorą się również $\mathrm{z}$ odmiennych wzorów zachowań $\mathrm{w}$ ramach pełnionych ról społecznych, odmiennych stylów życia czy zróżnicowanych postaw wobec zdrowia i choroby, które z kolei warunkowane są wieloma różnorodnymi czynnikami społeczno-kulturowymi, wśród których ważną rolę odgrywają stereotypy płci. Wykształcenie, dostęp do pracy, wykonywany zawód czy dochody różnicują dodatkowo w znacznym stopniu postawy wobec zdrowia i choroby. Płeć kulturowa (gender) kształtowana jest już w toku wczesnej socjalizacji i podtrzymywana przez strukturę społeczną, stąd wzory kulturowe w odniesieniu do kobiecości i męskości uwidaczniające się w wielu sferach życia społecznego dotyczą również praktykowania zachowań zdrowotnych zagrażających zdrowiu czy antyzdrowotnych. Mężczyźni i kobiety charakteryzują się odmiennym podejściem do dbania o zdrowie, do profilaktyki zdrowotnej, do zachowań zagrażających zdrowiu czy antyzdrowotnych. Stereotypy związane z płcią w istotny sposób wpływają na zdrowie somatyczne oraz psychiczne kobiet i mężczyzn (Slany, Kluzowa 2004; Slany, Struzik, Wojnicka 2011).

\subsection{PODSUMOWANIE}

Społeczeństwa krajów unijnych są w dużym stopniu zróżnicowane pod względem poziomu starzenia i dynamiki tego procesu. Proces starzenia się ludności nie jest zjawiskiem charakterystycznym tylko dla krajów najlepiej rozwiniętych gospodarczo, linia demarkacyjna pomiędzy krajami „starszymi” i „młodszymi” demograficznie nie pokrywa się z podziałem na „stare” i „nowe” kraje UE. Do grupy krajów o postępującym starzeniu się ludności dołączają kraje Europy Środkowo-wschodniej, które przed rozpoczęciem procesów transformacyjnych były względnie młode demograficznie. Konsekwencją starzenia się ludności jest wzrost obciążenia osób w wieku produkcyjnym ludźmi starymi, w większości krajów unijnych (22) odnotowano wzrost tego obciążenia.

Wśród czynników wpływających na jakość życia ludzi starych, ich stan zdrowia jest elementem bardzo istotnym, związanym z potrzebą subiektywnego odczuwania satysfakcji ze swojego pełnego potencjału zdrowotnego i pełnienia aktywnego życia społecznego. Także w przypadku stanu zdrowia mieszkańców Unii w wieku 65 lat i więcej i subiektywnego jego postrzegania można zaobserwować

tych, które mogą wywoływać anomalie czy choroby genetyczne. Jednak w przypadku garnituru chromosomowego u kobiet aberracje jednego z chromosomów X niwelowane są przez funkcje pozostałego. Ta właściwość chromosomów X daje kobietom ,przewagę genetyczną", gdyż anomalie tegoż chromosomu u mężczyzn częściej prowadzą do zaburzeń (istniejący drugi chromosom Y nie może zastąpić funkcji X). U kobiet choroby genetyczne występują wtedy, gdy uszkodzone są oba chromosomy X (Stillion 1995). 
duże zróżnicowanie przestrzenne. Jednak w tym przypadku stan zdrowia określony m.in. przez długość trwania życia i długość trwania życia w zdrowiu wskazuje na zależności pomiędzy poziomem rozwoju kraju a wysokością tych wartości.

Według koncepcji Lalonde’a na zdrowie społeczeństwa wpływają cztery grupy czynników: biologiczne (genetyczne), środowiskowe, style życia oraz system opieki zdrowotnej. Największy udział spośród tych czynników został przypisany stylowi życia - 53\%. Obecnie zwraca się uwagę, że w największym stopniu na zdrowie ludzi wpływają czynniki społeczno-ekonomiczne, a wśród nich m.in.: dochody, status społeczny, poziom wykształcenia, wsparcie społeczne. Od tych czynników zależy też, czy styl życia ludzi może sprzyjać zdrowiu (prozdrowotny). Ubóstwo, niski poziom wykształcenia są przyczyną nierówności w zdrowiu. Ludzie o niskim statusie społeczno-ekonomicznym mają gorsze zdrowie, podejmują częściej zachowania ryzykowne dla zdrowia, mają utrudniony dostęp do instytucji ochrony zdrowia. Wsparcie społeczne w środowiskach życia człowieka jest uważane za znaczący czynnik dla kształtowania pozytywnego zdrowia oraz przeciwdziałania chorobotwórczemu wpływowi potencjalnych stresorów. Koncepcja Banku Światowego zakłada, że stan zdrowia jest funkcją stanu zamożności i wykształcenia społeczeństwa. Sprzężenie zwrotne według tej koncepcji sprawia to, że stan zdrowia będzie tym lepszy, im społeczeństwo jest bardziej zamożne i wykształcone. Poprawa stanu zdrowia zwiększa szansę rozwoju kraju, a rozwój gospodarczy warunkuje wzrost zamożności obywateli, co z kolei daje im możliwość lepszego wykształcenia. Przyjmuje się, że największym zagrożeniem dla zdrowia jest ubóstwo i niski poziom wykształcenia (Nowak-Starz, Markowska, Król, Zięba, Szpringer 2013).

Dążenie do równości w zdrowiu jest jednym z pierwszych zadań $\mathrm{w}$ strategii ŚOZ Zdrowie 21. Realizacja tych postulatów jest trudna w okresie rozwoju gospodarki rynkowej, która w swym początkowym okresie powoduje rozwarstwienie społeczeństwa. Wymaga to większej troski i zaangażowania wszystkich podmiotów tworzących i realizujących politykę społeczną i zdrowotną (Zdrowie... 2001). Zdrowie 21 daje wykładnię etyczną i naukową dla decydentów oraz dla posługiwania się zdrowiem jako wskaźnikiem rozwoju we wszystkich dziedzinach polityki zdrowotnej regionu europejskiego.

\section{LITERATURA}

Avramov D., Maskova M., 2003, Active ageing in Europe, „Population Studies”, 41 (1), Council of Europe Publishing, s. 1-152.

Błędowski P., 2014, Ekonomiczne aspekty starzenia się ludności, [w:] Wyzwania XXI wieku. Ochrona zdrowia i kształcenie medyczne, Federacja Polskich Towarzystw Medycznych, Warszawa.

Burzyńska M., Marcinkowski J.T., Bryła M., Maniecka-Bryła I., 2010, Life Expectancy

$i$ Healthy Life Years jako podstawowe miary oceny sytuacji zdrowotnej ludności, „Problemy Higieny i Epidemiologii”, 91 (4), s. 261-274. 
Czarnecka K., 2004, Wybrane aspekty opieki nad starzejącym się społeczeństwem w Polsce, „Zdrowie i Zarządzanie”, 6(6), s. 10-19.

Długosz Z., 1996, Zróżnicowanie struktury wieku ludności na świecie a metody jej klasyfikacji, „Przegląd Geograficzny”, 68(1-2), s. 151-165.

Długosz Z., Kurek S., 2006, Demographic ageing of European Union countries, [w:] Komornicki T., Czapiewski K. (red.), Regional Periphery in Central and Eastern Europe, Europa XXI, 15, Polish Academy of Sciences, Stanisław Leszczycki Institute of Geography and Spatial Organization Centre for European Studies, Polish Geographical Society, Warszawa, s. 185-198.

Długosz Z., Kurek S., Kwiatek-Sołtys A., 2011, Stan i perspektywy starzenia się ludności w Polsce i Europie, [w:] Soja M., Zborowski A. (red.), Człowiek w przestrzeni zurbanizowanej, Instytut Geografii i Gospodarki Przestrzennej UJ, Kraków, s. 11-26.

Dyson T., 2001, A Partial Theory of World Development, The Neglected Role of the Demographic Transition in the Shaping of Modern Society, „International Journal of Population Geography", 7, s. 67-90.

Eurostat 2004, Ageing Population, [w:] Regions: Statistical Yearbook 2004, European Communities.

Frąckiewicz L., 2002, Monitoring $i$ kształcenie gerontologiczne, [w:] Frąckiewicz L. (red.), Polska a Europa. Procesy demograficzne u progu XXI wieku. Proces starzenia się społeczeństwa i jego wyzwania dla polityki społecznej, Katowice.

Frątczak E., 2002, Proces starzenia się ludności Polski, „Studia Demograficzne”, 2(142), s. 3-28.

Gałuszka M., 2006, Jakość życia seniora. Przegląd wybranych koncepcji i metod badania, [w:] Kowaleski J.T., Szukalski P. (red.), Starość i starzenie się jako doświadczenie jednostek i zbiorowości ludzkich, Zakład Demografii UŁ, Łódź, s. 111-118.

Golini A., 1997, Demographic trends and ageing in Europe. Prospects, problems and policies, „Genus”, 53(3-4), s. 33-74.

Golinowska S., Holzer J., Szwarc H., Pędich W., 1999, Starzenie się i starość: pojęcia, tendencje, cechy i struktury, [w:] Golinowska S. (red.), Ku godnej aktywnej starości. Raport o rozwoju społecznym. Polska 1999, UNDP, Warszawa.

Grundy E., 1996, Population ageing in Europe, [w:] Coleman D. (red.), Europe's population in the 1990s, Oxford University Press, New York.

King P., Jackson H., 2000, Public Finance Implications of Population Ageing, Department of Finance Working Paper, Department of Finance, Ottawa.

King R., Warnes A.M., Williams A., 1998, International retirement migration in Europe, „International Journal of Population Geography”, 4(2), s. 91-111.

Kinsella K., Phillips D.R., 2005, Global Aging: The Challenge of Success, „Population Bulletin", 60 (1), s. 3-40.

Kinsella K., Velkoff V. A., 2001, An Aging World: 2001, International Population Reports, https://www.census.gov/prod/2001pubs/p95-01-1.pdf.

Kotowska I., 1999, Przemiany demograficzne w Polsce $w$ latach 90. w świetle koncepcji drugiego przejścia demograficznego, Szkoła Główna Handlowa, Warszawa.

Kowaleski J.T., 2008, Struktura demograficzna starszego odłamu ludności (rozważania metodologiczne $i$ elementy obrazu sytuacji $w$ województwach $i$ powiatach na przetomie stuleci), [w:] Kowaleski J.T., Szukalski P. (red.), Starzenie się ludności Polski. Między demografia a gerontologia społeczną, Wydawnictwo UŁ, Łódź. 
Kurek S., 1998, Zróżnicowanie przestrzenne procesu starzenia się ludności Europy w latach 1960-1996 w świetle wybranych mierników, „Czasopismo Geograficzne”, 69 (3-4), Polskie Towarzystwo Geograficzne, Wrocław, s. 261-274.

Kurek S., 2008, Typologia przestrzenna ludności Polski w ujęciu przestrzennym, „Prace Monograficzne AP”, 497, Wydawnictwo Naukowe Akademii Pedagogicznej, Kraków.

Lauder R.H., 1998, Social Problems and the Quality of Life, McGraw-Hill, Boston.

Michalski T., 2010, Sytuacja zdrowotna $w$ europejskich krajach postkomunistycznych $w$ dobie transformacji, Wydawnictwo Uniwersytetu Gdańskiego, Gdańsk.

Michalski T., 2012, Przemiany umieralności w Europie Środkowej i Środkowo-Wschodniej w okresie transformacji, Wydawnictwo Bernardinum, Pelplin.

Mirkin B., Weiberge M., 2001, The demography of population ageing, „United Nations Population Bulletin", Special Issue Nos. 42/43, s. 41-58.

Nowak-Far A., 2011, Methuselach Perplexus - polityka prawa wobec zmian demograficznych w Europie, [w:] Osiński J. (red.), Współczesne problemy demograficzne. Rzeczywistość i mity. Ujęcie krajowe, regionalne i globalne, Oficyna Wydawnicza SGH, Warszawa, s. 283-304.

Nowak-Starz G., Markowska M., Król H., Zięba E., Szpringer M., 2013, Medyczne koncepcje struktury zdrowia, jego ochrony i promocji, „Zdrowie i dobrostan”, 1, s. 149-162.

Okólski M. (red.), 1990, Teoria przejścia demograficznego, PWE, Warszawa.

Okólski M., 2005, Demografia. Podstawowe pojęcia, procesy i teorie w encyklopedycznym zarysie, Wydawnictwo Naukowe Scholar, Warszawa.

Pierzchalska A., Klag P., 2008, Społeczne role osób starszych, [w:] Bokajło W., Pacześniak A. (red.), Równość w Unii Europejskiej. Teoria i praktyka, Wrocławskie Wydawnictwo Naukowe Atla 2, Wrocław.

Reher D.S., 2004, The demographic transition revisited as a global process, „Population, Space and Place", 10, s. 19-41.

Slany K., Kluzowa K., 2004, Kształtowanie systemu wartości jako kierunek działań polityki ludnościowej, [w:] Graniewska D. (red.), Sytuacja rodzin i polityka rodzinna w Polsce. Uwarunkowania demograficzne i społeczne, IPiSP, Warszawa.

Slany K., Struzik J., Wojnicka K. (red.), 2011, Gender w społeczeństwie polskim, Nomos, Kraków.

Stan zdrowia ludności Polski 2009, 2011, GUS, Warszawa.

Stillion J.M., 1995, Premature Death among Males, [w:] Sabo D., Gordon D.F. (red.), Men's Health and Illness, Thousand Oaks: Sage.

Szukalski P., 1998, Starzenie się społeczeństw Europy: spojrzenie perspektywiczne, „Gerontologia Polska", 2, s. 51-55.

Szukalski M., 2004, Osoby sędziwe w Polsce $i$ w krajach Unii Europejskiej - przeszłość, przyszłość i teraźniejszość, „Prace Instytutu Ekonometrii i Statystyki UŁ”, seria A, 142.

Szukalski M., 2006, Populacja osób bardzo starych w społeczeństwie polskim - stan obecny i perspektywy, [w:] Kowaleski J.T. (red.), Ludzie starzy w polskim spoleczeństwie w pierwszych dekadach XXI wieku, Wydawnictwo UŁ, Łódź, s. 115-150.

Szukalski P., 2008, Starzenie się ludności-wyzwanie XXI wieku, [w:] Szukalski P. (red.), To idzie starość - polityka społeczna a przygotowanie do starzenia się ludności Polski, Instytut Spraw Publicznych, Warszawa. 
van de Kaa D.J., 1994, The second demographic transition revisited: Theories and expectations, [w:] Beets G. i in. (red.), Population and family in the Low Countries 1993: Late fertility and other current issues, NIDI/CBGS Publication, 30, Swets and Zeitlinger, Berwyn, Pennsylvania/Amsterdam.

Walker A. (red.), 2014, The New Science of Ageing, Policy Press, Bristol.

Wróblewska W., 2008, Sumaryczne miary stanu zdrowia populacji, „Studia Demograficzne", 153-154(1-2), s. 3-53.

Zdrowie 21. Zdrowie dla wszystkich w XXI wieku, 2001, Centrum Systemów Informacyjnych Ochrony Zdrowia, Uniwersyteckie Wydawnictwo „Vesalius”, Warszawa-Kraków.

\begin{abstract}
Population ageing has been observed in the 28 countries of the EU for many years. It is a spatially diverse process. The growing percentage of the elderly people influences the health of societies.

The health state of the elderly is, among the factors influencing their quality of life, a crucial element associated with the need for the subjective feeling of satisfaction with a fulfilment of the health potential and an active social life. The purpose of the work is to present the selected aspects of the ageing process in the countries of the EU and the selected aspects of the characterisation of the EU inhabitants aged 65 and above in terms of health.
\end{abstract}

\title{
Key words
}

Population ageing, population health state, subjective assessment of health state, 28 countries of EU. 